\title{
過疎地・地方都市で働く外国人介護者
}

——経済連携協定によるフィリピン人介護福祉士候補者49人の追跡調査から—

\section{Foreign Care Workers in Underpopulated Areas and Local Cities:}

Follow-up Research on 49 Certified Filipino Care Worker Candidates

under the Japan-Philippines Economic Partnership Agreement

\section{高畑 幸 \\ Sachi TAKAHATA}

Japan's declining population is severely impacting rural areas and cities and causing shortages of care workers. In recent years, Indonesian and Filipino candidates are coming to Japan under the economic partnership agreement (EPA) program to take the country's certified care worker license (kaigo-fukushishi) exam after completing three years of onthe-job training at care facilities nationwide. However, Japan's initial attempt to import foreign care workers was far from completely successful; even though the government subsidized the costs for learning Japanese and taking the national exams, many candidates returned to their home countries. For the first batch of Filipino kaigo-fukushishi candidates who came in 2009, only around 30\% passed the exam in January 2013. Based on follow-up research of 49 from the first batch of Filipino candidates, this paper answers the following two questions: What attributes of candidates ease settlement at rural care facilities? What attributes and working experiences are necessary for successful examinees? Our findings suggest that (1) Internet access at care facilities is crucial to ease the settling of candidates, and (2) candidates who are already qualified nurses in their home country but decided to become care workers in Japan have an advantage in taking the national exam because of their basic medical knowledge. On the other hand, since the international labor market demand for Filipino nurses is high, the possibility always exists that they might move to another country.

\section{1. 問題設定}

少子高齢化および都鄙格差の拡大という日本社会の問題と、国際労働力移動の加速とい うグローバルなトレンドが必然的に接合した領域が、近年の外国人介護労働者の受入れで ある。2008年から始まつた経済連携協定（EPA）による外国人介護福祉士候補者の来日は、 日本が初めて経験する公式経路での外国人ケア労働者の受入れとなった。しかし、後述す るように、彼 (女) らの定着および国家試験の合格には課題が多い。国家試験の受験には 3 
年の実務経験 (就労) が必要だが、過疎地・地方都市の施設では試験前に中途帰国する事 例が多くみられた。結論を先取りすると、国際移動をする高学歴中間層の労働者が持つ都 市的流動性と受入れ施設の土着性とが衝突した結果が中途帰国とも考えられるのである。 本論は、 2009 年 5 月に入国したフィリピン人介護福祉士候補者 1 期生を対象として、(1) ど のような属性の候補者が 3 年間、定着したのか、(2)どのような属性の候補者が介護福祉士 国家試験に合格したのか、の 2 点に答えようとする仮説索出的研究である。

上記の問いを、フィリピン人介護福祉士候補者 1 期生合計 190 人のうち、西日本に配属 された 49 人の追跡調査から明らかにしたい。EPAによる外国人ケア労働者への日本語お よび介護福祉教育には多額の税金が投じられている。彼（女）らの定着および国家試験合 格は、国民の税金の有効利用か浪費かという問題にもつながる。そして本研究で意図され る社会的および学問的貢献は、(1)今後の候補者選定や受入れ施設での態勢作り・学習支援 に役立てる1)、(2)フィリピン人の国際労働力移動の側面から EPAによるケア労働者の送 出・受入れを再考する、の 2 点である。

以下では、まず、EPAによる介護福祉士候補者の受け入れに関する制度概要を論じた 後、本研究の調査対象である 49 人のデータを示しつつ、日本での定着および国家試験合 格への個人的および社会的条件について考察を加えたい。なお、EPAではこれまでインド ネシア、フィリピン、ベトナムから看護師および介護福祉士候補者を受け入れてきた。し かし、本論では「フィリピン人介護福祉士候補者」に議論を絞りたい。その理由は、(1)そ の 1 期生の来日時から国家試験を経て帰国までの約 4 年間の追跡調査ができたこと、(2)看 護師と介護福祉士は資格認定の根拠法、来日時の資格要件および国家試験受験可能回数が 違うため、両者を同時に論じることは不可能であること、の 2 点である。

\section{2. 経済連携協定による介護福祉士候補者の受入れ}

\section{1 受入れ概要 ${ }^{2)}$}

厚生労働省のウェブサイトでは、EPAによる介護福祉士候補者受入れの制度につき詳細 に情報公開されている。そこでは第一に、これは「外国人の就労が認められていない分野 において、二国間の協定に基づき公的な枠組みで特例的に行うもので、介護現場の人手不 足対策ではない」ことが強調される。そして、二国間協定であるEPAでは、フィリピン 側の募集・送出機関は同国の労働雇用省管轄である海外雇用庁のみであり、日本側は公益 社団法人国際厚生事業団が唯一の斡旋機関である。民間の斡旋会社の参入はできない。

看護師候補者と介護福祉士候補者の大きな違いは、応募要件にある。介護福祉士は日本 独自の資格である。そのため、フィリピンで 4 年制大学卒業後、半年間の介護研修を修了 した人ならばEPAに応募可能だ。後述するように、候補者たちの職歴はさまざまであ る。これに対し、看護師候補者となるためには、フィリピンで 3 年以上、看護師としての 
就労経験が必要となる。なお、両者ともに応募時の日本語能力は問われない。2009年入 国の 1 期生の場合、来日後、半年間の日本語研修を受け、施設へ配属されていた ${ }^{3)}$ 。

制度発足当初の 2009 年と 2010 年度は、介護福祉士候補者は専門学校に通いながら週 28 時間を限度に施設で働く「就学コース」とフルタイムで施設勤務をする「就労コース」に 分かれていたが、2011年度以降は「就労コース」に一本化された ${ }^{4)}$ 。本研究で対象とする のは「就労コース」である。候補者は介護福祉士の国家資格を取得することを目的とし て、既定の滞在期間（4年間）に「特定活動」の在留資格で就労・研修する。介護福祉士 の場合、3 年間の実務経験があって初めて受験資格が発生するため、4 年間の滞在期間中 に受験機会は一度のみとなる。施設での就労中、候補者と受入れ機関とは雇用契約を結ん でおり、日本人と同等の報酬を受け取り、他施設へ転職できない。また、彼(女) らにも 日本の労働関係法令や社会・労働保険が適用される。国家試験に合格して介護福祉士資格 を取得すれば、その後は介護福祉士として無期限で滞在延長でき、家族の呼び寄せも可能 だ。

2009 年度から 2013 年度までの受入れ人数は【表 1】の通りである。

表 1 EPAによるフィリピン人看護師・介護福祉士候補者の受入れ人数

\begin{tabular}{|c|c|c|c|c|c|}
\hline & \multirow{3}{*}{ 看護師候補者 } & \multirow{2}{*}{\multicolumn{2}{|c|}{ 介護福祉士候補者 }} & \multirow{3}{*}{ 合計 } \\
\hline & & & & & \\
\hline & & & 就労コース & \multirow{2}{*}{$\begin{array}{r}\text { 就学コース } \\
27\end{array}$} & \\
\hline \multirow{3}{*}{ 2009年度 } & 入国人数 & 93 & $190(10)$ & & $310(10)$ \\
\hline & 入国日 & $2009 / 5 / 10$ & $2009 / 5 / 10(2009 / 5 / 31)$ & $2009 / 9 / 27$ & \\
\hline & 就労・就学開始日 & $2009 / 10 / 29$ & $2009 / 11 / 11(2009 / 6 / 10)$ & $2010 / 4 / 1$ & \\
\hline \multirow{3}{*}{ 2010年度 } & 入国人数 & 46 & $72(2)$ & 10 & $128(2)$ \\
\hline & 入国日 & $2010 / 5 / 9$ & $2010 / 5 / 9(2010 / 6 / 8)$ & $2010 / 9 / 26$ & \\
\hline & 就労・就学開始日 & $2010 / 10 / 29$ & $2010 / 11 / 11(2010 / 6 / 17)$ & $2011 / 4 / 1$ & \\
\hline \multirow{3}{*}{ 2011年度 } & 入国人数 & 70 & $61(1)$ & $=$ & $131(1)$ \\
\hline & 入国日 & $2011 / 5 / 29$ & $2011 / 7 / 18(2011 / 6 / 8)$ & $=$ & \\
\hline & 就労開始日 & $2011 / 11 / 17$ & $2012 / 1 / 19(2011 / 6 / 17)$ & - & \\
\hline \multirow{3}{*}{ 2012年度 } & 入国人数 & 28 & $73(2)$ & - & $101(2)$ \\
\hline & 入国日 & $2012 / 5 / 27$ & $2012 / 5 / 27(2012 / 5 / 29)$ & - & \\
\hline & 就労開始日 & $2012 / 11 / 23$ & $2012 / 11 / 23(2012 / 6 / 8)$ & - & \\
\hline \multirow{3}{*}{ 2013年度 } & 入国人数 & 64 & $87(6)$ & - & $150(6)$ \\
\hline & 入国日 & $2013 / 6 / 19$ & $2013 / 6 / 19(2013 / 5 / 28)$ & $=$ & \\
\hline & 就労開始予定日 & $2013 / 12 / 17$ & $2013 / 12 / 17(2013 / 6 / 7)$ & $=$ & \\
\hline 累計 & 入国人数 & 301 & $483(21)$ & 37 & $821(21)$ \\
\hline
\end{tabular}

（注：カッコ内の日付および数は、日本語研修免除者。出典：厚生労働省ウエブサイトより筆者作成） 


\section{2 制度としてのEPAの特殊性、その当事者}

一般にEPAは二国間の貿易促進を目的とした協定である。しかし、本論でいう2006年 締結の日比EPAは、初めての「人の移動」を伴うEPAであり、日本にとっては公式経路 でのケア労働者の受入れとなった。そこには 4 つの当事者がいる。各々の当事者にとって のEPAの特殊性と EPAへの期待をまとめておこう。

第一の当事者は国である。フィリピン側は海外雇用庁が人材募集の空口となった。来日 後の候補者たちは公益社団法人国際厚生事業団を通じて受入れ施設へ配属され、候補者の 日本語・介護福祉教育のコストは税金でまかなわれている。例えば、平成 24 年度の学習 支援関連予算は 3 億 7,800 万円 ${ }^{5)}$ であった。

第二の当事者が、受入れ法人・施設である。マニラで行われる合同企業説明会で受入れ 法人の担当者が候補者と面接し、マッチングを経て 3 年間の労働契約（期間中の転職不可） を結ぶ。後述する中井久子 [2011] の調査によると、施設側は人材供給源としてのEPAに 期待を持っていたことが示唆される。過疎地の介護施設では介護職員不足はより深刻であ る。施設を訪問すると「(たとえ介護福祉士試験に不合格となっても) 実際、 3 年間働い てくれるのはありがたい」という施設長もいた。

第三の当事者が、候補者たちである。聞き取りから、彼 (女) らにとって EPAの特殊性 は「自己負担なしで海外就労ができる」ことだと言える。通常、海外就労をするためには 民間の斡旋企業へ多額の斡旋料を支払い、旅費も自己負担である ${ }^{6)}$ 。EPAの場合はいずれ も無料と初期投資がいらず、 3 年間の雇用が確保できる魅力がある。

第四の当事者が、地方自治体である。候補者の学習支援への補助金は、厚生労働省から 県 (介護保険課等) を通じて受入れ施設へ配分される。県や市町がどれほどEPA候補者へ 「関与」するかは各自治体に委ねられている。例えば、静岡県は比較的積極的に関与して いる事例だ。2010年、県内のEPA受入れ施設が連絡協議会を作り、定例会合には県の介護 保険課職員や研究者が同席するほか、県の助成金を得て独自にテキストを作成している。

以上をまとめると、厚生労働省はEPAによるケア労働者の受入れは「労働力不足対策 ではない」としているものの、施設と労働者は「労働力」と「雇用」を求めてEPAとい う「橋」を利用し両国を往来しているようだ。そして、【表1】で示したように、すでに 多数の外国人ケア労働者が、日本各地の病院や介護施設で働いている。

\section{3. 先行研究}

\section{1 さまざまな学問分野からのアプローチ}

2008年から始まったEPAによる看護師・介護福祉士の受入れについては、社会学のみ ならず、複数分野の研究者が調查を進めている。彼（女）らの来日以前から、ケア労働者 の国際移動研究には伊藤るり、落合恵美子らが取り組んでいた。また、EPAの政策・制度 
の概説と評価および国際比較は、大野俊、小川玲子、平野裕子、安里和晃らが担ってい る。特に、大野・小川・平野を中心とする九州大学アジア総合政策センター所属教員（当 時）グループによる研究の蓄積は重厚かつきめ細かい。また、フィリピン研究者でもある マリア・レイナルース・D・カルロス、安里和晃らは、フィリピンの労働力輸出政策の側 面から EPAの政策・制度を分析してきた。

さらには、看護、介護、日本語教育の研究者も EPAによるケア労働者の受入れの研究 に着手している。例えば、日本語教育では、立川和美、川村よし子、布尾勝一郎、岩田一 成らである。「看護／介護の日本語」は、日本語教育の新分野となっている。また、介護 福祉教育では、それまで在日フィリピン人介護者を調査してきた中井久子、後藤由美子ら が EPAの介護福祉士候補者の研究を進めている。

\section{2 本調査に関連するもの}

上記に挙げた各分野の先行研究の中で、特に本研究に関連すると思われるものを以下に 3 点紹介したい。マリア・レイナルース・D・カルロス [2012] は、多段階的国際移動が フィリピン人の移動文化のひとつのスタイルだという。例えば、ドバイはフィリピン人看 護師にとつて仕事を見つけやすい場所だが、労働条件には不満が残る。ここは「第一段階 の出国先」とされ、看護師たちはその後、英国やアメリカ、カナダ等、英語圈の先進国へ の転職を考えることが多い。斡旋料・渡航費の自己負担がない日本を、次なる定住先への 待機場所として利用するだけの看護師や介護士がいるのではとカルロスは懸念している。

平野裕子 [2010］は、受入れ施設には規模や職員数等の条件が課せられており、また定 期的に国際厚生事業団職員による巡回指導があるため、現在のところ、外国人看護師は一 定レベルの病院で勤務できることを評価している。一方、Mireille Kingma [2006] の看護 師の国際移動理論を引き、看護師たちは行き先の国で得られるメリット（生活の質、キャ リアアップの可能性、家族の呼び寄せ等）を慎重に検討するという。厚生労働省は EPA によるケア労働者の受入れを「労働力不足対策ではない」としているが、「その部外者的 な認識は、もはや国際社会では通用しない」と平野は指摘する。

中井久子 $[2011]$ は、フィリピン人看護師および介護福祉士候補者 1 期生を受け入れる 135 施設（うち看護 45、介護 92）を対象に質問紙調査を行っている。それによると、「日 本人職員への刺激」「国際協力」を受入れの動機としながらも、「今後 5 年間に職員不足を 懸念している」施設が8割にのぼることが明らかになった。「人手不足ではない」という 厚生労㗢省の「建前」と、介護現場の「本音」は食い違う。

平野 [2010］は看護師候補者を対象とし、中井［2011］とカルロス［2012］は介護福祉士 候補者をも対象とした分析である。看護師の国際移動についてはKingma等の先行研究が あるが、介護士はその職業としての歴史が浅いことから、いまだ研究は少ない。さらに は、EPAにより来日した候補者たちの入国から国家試験受験までの定点観測に基づいて 
「どのような人が、どのような条件で定着し合格するか」という問いに答える研究はまだ 存在しない。それを明らかにする試みが本論である。

\section{49 人の追跡調査から}

\section{1 調查の概要}

本調査の対象は、経済連携協定によるフィリピン人介護福祉士候補者 1 期生合計 190 人 のうち、広島で日本語研修（2009年 5 月〜 11月上旬）を受けた後に西日本の施設へ配属さ れた 49 人である。日本語研修を受託した（財）ひろしま国際センター研修部の依頼で、筆 者が彼 (女) らを対象に日本人とのコミュニケーションに関するワークショップ等を担当 し、そこで彼 (女) らと対面的に知り合った。その後、訪問、メール、フェイスブック等 で連絡を取り合い、来日時から国家試験受験、その後の残留/帰国までを定点観測するこ とができた。時には、電話や訪問により候補者と施設担当者との通訳をしたこともある。

これまで行った調查は、(1)質問紙調查（2009年 9 月、2009年10月)、(2)施設訪問調查 (2009年 12 月、 2010 年 8 月、 2011 年 8 月、 2012 年 8 月)、(3)帰国者調查（マニラにて 2010 年 8 月、 2012 年 2 月、 2013 年 9 月。ドバイにて 2013 年 3 月）の 3 種類である。(1)は、(財) ひろしま国際センター研修部の協力を得て、フィリピン語の質問票を作成し対象者全員か ら回答を得た。(2)は、受入れ施設（訪問が許可された合計 20 カ所）を訪問し、候補者およ び教育担当者に話を聞いた。(3は、2013年 1月の国家試験以前に中途帰国した候補者たち に直接連絡をとり、マニラおよびドバイで面接を行った。

\section{2 来日動機と配属先}

以下では、 49 人の来日から時系列的に出来事を紹介したい。2009年 9 月の質問紙調查に

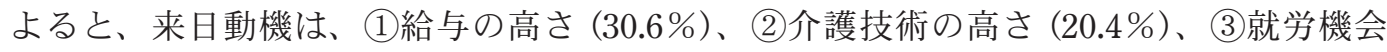
(18.4\%)、(4)日本で介護資格を取りたい $(12.2 \%) 、(5)$ 日本で生活してみたい $(8.2 \%) 、 の$ 順であった。

広島で日本語研修を受けた 49 人は、 2009 年 11 月、西日本の 9 県 20 市町にある 21 法人の 24 施設へ配属された。受入れ施設がある20市町の高齢化率平均は $25.5 \%$ (全国平均 $23.1 \%$ )、外国人人口比率平均は $0.66 \%$ (同 $1.67 \%$ ) である。また、 20 市町中、過疎地域自 立促進特別措置法による「過疎地域市町村」が 5 市町、「過疎のある市町村（合併前の町 村が過疎地域)」が 10 市町ある7)。従って、候補者たちの多くが働くのは「高齢化が進み 外国人が少ない過疎地」だと言えよう。

筆者の訪問先だけでも、1980 年代後半に嫁不足で外国人花嫁を受入れた村の近くにある 施設や、最寄り駅から車で 30 分、周りは山と水田ばかりで、ショッピングモールがある 街へ出るには電車やバスで 2 時間がかりという場所もある。英語を話せる職員がいる施設 
はごく少数だ。ほとんどの候補者たちは日本での生活経験および土地勘がなく、インター ネット上の「日本＝東京の豊かさ」イメージを持つ。そのため、日本語研修中に施設見学 をして初めて赴任先が過疎地にあることを知り、嫌がる候補者もいたと後から聞いた。換 言すれば、受け入れ側（施設経営者、職員、利用者）にとつて候補者は「人生で初めて間近 に接する外国人」となり、候補者側からすれば、見知らぬ土地で「外国人慣れしていない 人たち」と学習開始からわずか半年という日本語能力で接する日々が始まったのである。

\section{3 配属先での就労と学習}

候補者は配属先で 3 年間の実務経験を積夕ながら日本語学習を進め、2013 年 1 月に介護 福祉士の国家試験を日本語で受験しなければならない。「介護福祉士試験の合格」が共通 のゴールとなるわけだが、それに至るプロセスは配属された施設によりさまざまだ。すな わち、学習時間数の確保（就業時間内に勉強させるか否か）、誰が候補者たちに教えるか は、施設によりまつたく違う。異なる条件で同一の結果が求められるのである。また、給 与や待遇も施設間で違う。日本語研修の半年間、同じ屋根の下で生活した 49 人は施設配 属後もフェイスブックで連絡をとりあった。これら学習支援および待遇の施設間格差は瞬 時に候補者間で知れ渡り、それを材料に待遇改善の交渉を始める者もいた。

教材や学習支援コストは国際厚生事業団から各施設へ提供された。例えば、(1)就労開始 から国家試験までの「標準的学習プログラムと研修の手引き」提供、(2)日本語講師の受入 れ、日本語学校への通学コストの補助、(3)模擬試験、介護技術講習会への参加費補助、(4) 学習支援に必要な備品購入費補助、(5)受入研修担当者への手当補助、6)入国年度別の集合 研修と模擬試験実施、(7)候補者向け国家試験対策教材配布、8)相談空口（電話）設置（英 語、インドネシア語) 等である。

加えて、EPAの候補者たちに有利となる在留制度および国家試験の配慮が導入されてい る。例えば、(1)従来はEPAの候補者の賃金は全額施設負担だつたが、2013年 4 月より、候 補者も介護保険の対象人員となった。(2)日本語学習支援体制が不十分だった 2009 年度・ 2010 年度入国の候補者は、国家試験不合格でもスコアにより 1 年間滞在を延長して再受 験できる。(3)護福祉士の試験問題は漢字にルビ振り、医療用語は英語併記となった。こ のように、国を挙げて候補者たちを勉強させ、合格させる努力がなされたのである。

\section{4 どのような人が定着したのか}

厚生労働省の発表によると、フィリピン人介護福祉士候補者 1 期生として、2009年 5 月 に 190 人が来日したものの、2013 年 1 月に介護福祉士試験を受験したのは 138 人（定着率 $72.6 \%)$ であった。この時点で、 52 人 $(27.4 \%)$ が中途帰国していたことがわかる。そし て、本研究の追跡対象である 49 人中、国家試験までに 21 人 (42.9\%) が帰国しており、受 験者は 28 人（定着率 $57.1 \%$ )、合格者は 9 人（受験者に対する合格率 $32.1 \%$ ) であった。本 
表 2 マニラ首都圏出身者の中途帰国

\begin{tabular}{|c|c|c|c|c|c|c|c|c|c|}
\hline ID & 生年 & 性別 & 合否 & 現住地 & 大学での専攻 & 出身地 & 職歴 & 海外就労経験 & 来日動機 \\
\hline 8 & 1975 & $\mathrm{~F}$ & 中途帰国 & フィリピン & 経営 & マニラ首都圈 & 店員、秘書 & $\times$ & 介護技術の高さ \\
\hline 21 & 1986 & $\mathrm{~F}$ & 合格 & 日本 & 看護 & マニラ首都圏 & 役員秘書 & $\times$ & $\begin{array}{l}\text { 日本で介護資格 } \\
\text { を取る }\end{array}$ \\
\hline 31 & 1981 & $\mathrm{~F}$ & 中途帰国 & フィリピン & 工学 & マニラ首都圏 & $\begin{array}{l}\text { 技術職員、IT操 } \\
\text { 作研究員 }\end{array}$ & $\times$ & $\begin{array}{l}\text { 日本で介護資格 } \\
\text { を取る }\end{array}$ \\
\hline 32 & 1970 & $\mathrm{~F}$ & 中途帰国 & フィリピン & 無回答 & マニラ首都圏 & $\begin{array}{l}\text { 技術職員、IT操 } \\
\text { 作調查員 }\end{array}$ & $\begin{array}{l}\text { リヤド、1年 } \\
\text { 未満 }\end{array}$ & 介護技術の高さ \\
\hline 33 & 1972 & $\mathrm{~F}$ & 中途帰国 & フィリピン & 看護 & マニラ首都圏 & 看護師 & $\times$ & 給与の高さ \\
\hline 40 & 1978 & $\mathrm{~F}$ & 不合格 & 日本 & 経済 & マニラ首都圏 & 電子機械操作 & $\begin{array}{l}\text { 台湾、3 年 } \\
\times 2 \text { 回 }\end{array}$ & $\begin{array}{l}\text { 斡旋手数料が低 } \\
\text { い }\end{array}$ \\
\hline 44 & 1980 & M & 合格 & 日本 & 心理 & マニラ首都圈 & $\begin{array}{l}\text { 会社員、教会ボ } \\
\text { ランティア }\end{array}$ & $\times$ & $\begin{array}{l}\text { 日本で介護資格 } \\
\text { を取る }\end{array}$ \\
\hline 45 & 1980 & $\mathrm{~F}$ & 中途帰国 & フィリピン & コンピュータ & マニラ首都圏 & データ入力 & $x$ & 介護技術の高さ \\
\hline
\end{tabular}

(出典：筆者作成)

調査の対象者は、全国平均に比べて定着率が低かったことは明らかだ。

それでは、どのような人が 3 年間、定着したのだろうか。まず、 49 人の属性を示すデー 夕からみると、マニラ首都圈出身者は 8 人で、そのうち中途帰国が 5 人 (62.5\%) と高い 【表2】。やはり都会育ちの候補者たちには、配属先の介護施設がある過疎地ではカル チャーショックが大きかったのか。以下に定着事例と中途帰国事例をいくつか紹介した い。

\subsection{1 定着し合格 : 候補者 3 人で力を合わせ、送金のため働く}

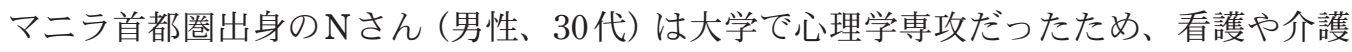

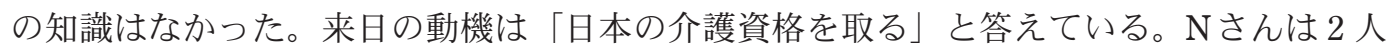
のフィリピン人候補者とともに、最寄り駅まで自転車で 50 分という四国の山間部にある 施設に配属された。施設の日本人職員は地元で生まれ育つた人が多く、方言がきつい上 に、Nさんたちが意思疎通に困難を伴うという状態が理解されず、彼 (女) らが一方的に 叱られることもあつた。一時は学習意欲が減退したものの、eラーニング（インターネッ トを利用した対面型授業）を利用すると勉強への意欲が増したという。3 人は同じ借家に 住み、力を合わせて勉強した。他の候補者に比べて実家が貧しく、Nさんは常に家族へ送 金する必要に迫られており、中途帰国という選択肢はなかつた。国家試験までに一時帰国 することもなく、働いては勉強した。彼の場合、送金という明らかな来日目的があり、試 験合格はその後の日本滞在と送金の継続を保証する道具である。そのため、居住地が都会 か田舎かはあまり問題にならなかった。そして、Nさんからの送金で、弟はサウジアラビ ア、妹は香港へ出稼ぎに行くための斡旋料を工面することができた（2011年 8 月、四国地 方にて聞き取り、2013年 4 月、メールで連絡有)。 


\subsection{2 定着したが不合格：過疎地での暮らしを好む}

マニラ近郊出身のフィリピン人 $\mathrm{G}$ さ（男性、30代）は、中東での出稼ぎを経て $\mathrm{EPA}$ で 来日し、中国地方の山間部にある介護施設に着任した。施設がある町の高齢化率は $40 \%$ を超える。候補者の GさんとJさん（男性、20代）は「若者の移住者」として地域の人び とにかわいがられた。まず、近所の人たちが野菜や米をくれる。彼らは一軒家を共同で借 りて生活していたが、帰宅すると家の前に野菜が置いてあることはしょつちゅうだつた。 大家さんは「若いふたりが来てくれて嬉しい。みんな応援しているよ」と言う。隣町の工 場に技能実習生がいるくらいで、他に外国人はほとんどいない場所である。隣接市に力ト リック教会があるが英語ミサはない。そのかわり、月に一度、日曜日に高速バスに 2 時間 乗って都市部へ行き、カトリック教会に行って候補者仲間に会い、気分転換をする。カメ ラが趣味の Gさんは、日本の四季折々を撮影し、インターネット上で写真展を開くなどし て楽しんだ。訪問すると「介護の仕事が楽しい。お年寄りを自分の祖父母のように感じ る。でも、試験勉強は難しい」とGさんは言い、教育担当の上司も「Gさんは仕事が丁寧 で、利用者さんたちの人気者。国家試験さえなければねえ‥」と言葉を濁していた。結 局、不合格となった $\mathrm{G}$ さんは帰国を決意した（2012 年 8 月、中国地方にて聞き取り、2013 年 4 月、メールで連絡有)。

\subsection{3 定着せず中途帰国 : 過疎地に耐えられず、引きこもり、帰国}

$\mathrm{K}$ さ（女性、30代）はマニラ首都圈で生まれ育った。大学では化学を専攻し、来日前 は中小企業で事務員をしていたが、「海外出稼ぎに行きやすい職だから」と家族に勧めら れて介護資格をとった。海外生活も一人暮らしも初めてである。

配属先の施設は過疎地にあり、最寄り駅から車で 20 分かかる。日本人職員は自家用車 で通勤するが候補者たちには自転車しか移動手段がない。施設から寮まで自転車で 40 分 かかる。施設から寮までは山と田んぼと川で、まばらに住宅があるくらいだ。フィリピン では自転車に乗る習慣がなく、日本で初めて自転車に乗つた。雨の中、自転車をこいで 帰つた時は「本当に惨めな気持ちになった」という。また、手取り給与から家顀と食費を 引くと、思ったほど貯金できないことも労働意欲が減退する原因となった。「日本に来 て、自分の無力さに情けなくなった」という $\mathrm{K}$ しは、あまりの孤独と辛さに引きこも り、仕事を休んで家でインターネットばかりを見るようになつた。心配した実家から帰り の航空券が送られてきて、2010年7月に帰国し、マニラで医療機関の事務員として再就職 した。

2013 年 9 月、マニラの大規模ショッピングモール内でKさんと食事をした。仕事帰りの 彼女はミニスカートにハイヒールのいでたちで、食後はモール内のファッションブランド 店をのぞき「やっぱり、私にはこういう空間が必要なの」と言つた（2010年 6 月、四国地 方にて聞き取りの後、 2013 年 9 月、マニラにて聞き取り)。 
表 3 介護福祉士試験の合格者 9 人のプロフィール

\begin{tabular}{|c|c|c|c|c|c|c|c|c|}
\hline ID & 生年 & 性別 & 現住地 & 大学での専攻 & 出身地 & 職歴 & 海外就労経験 & 来日動機 \\
\hline 7 & 1986 & $\mathrm{~F}$ & 日本 & 看護 & ルソン島 & なし (新卒) & $\times$ & 介護技術の高さ \\
\hline 10 & 1972 & $\mathrm{M}$ & 日本 & 工学 & セブ島 & $\begin{array}{l}\text { 機械操作、システムエンジ } \\
\text { 二ア、住みみ込み介護士 }\end{array}$ & $\begin{array}{l}\text { 台湾、機械操 } \\
\text { 作 }\end{array}$ & 介護技術の高さ \\
\hline 12 & 1976 & $\mathrm{~F}$ & 日本 & 医療技術 & ルソン島 & $\begin{array}{l}\text { 医療技術者、薬剤営業、薬 } \\
\text { 局助手 }\end{array}$ & $x$ & 給与の高さ \\
\hline 15 & 1982 & $\mathrm{M}$ & 日本 & 林業 & ミンダナオ島 & 製造業、介護士 & $\times$ & $\begin{array}{l}\text { 日本で介護資格 } \\
\text { を取る }\end{array}$ \\
\hline 17 & 1981 & F & フィリピン & 情報技術 & ルソン島 & 機械操作、政府機関事務員 & $\begin{array}{l}\text { 台湾、機械操 } \\
\text { 作 }\end{array}$ & 給与の高さ \\
\hline 21 & 1986 & F & 日本 & 看護 & マニラ首都圏 & 役員秘書 & $x$ & $\begin{array}{l}\text { 日本で介護資格 } \\
\text { を取る }\end{array}$ \\
\hline 23 & 1985 & F & 日本 & 看護 & ルソン島 & $\begin{array}{l}\text { 個人雇用看護師、院内看護 } \\
\text { 講師 }\end{array}$ & $x$ & 就労機会 \\
\hline 42 & 1972 & F & 日本 & 看護 & ルソン島 & 看護師、住み込み介護士 & $\begin{array}{l}\text { イスラエル、 } \\
\text { 介護士 }\end{array}$ & 介護技術の高さ \\
\hline 44 & 1980 & $\mathrm{M}$ & 日本 & 心理 & マニラ首都圈 & 会社員、教会ボランティア & $x$ & $\begin{array}{l}\text { 日本で介護資格 } \\
\text { を取る }\end{array}$ \\
\hline
\end{tabular}

（出典：筆者作成）

\section{5 どのような人が合格したのか}

それでは、どのような人が合格に至ったのだろうか。繰り返しになるが、1 期生全体で は、190人が入国して 138 人受験、そのうち 42 人合格という結果であった ${ }^{8)}$ 。そして、本 研究の追跡対象の 49 人のうち、9人が合格している。サンプル数の限界から、合格者と属 性との相関関係は統計的に明らかにならなかったが、傾向として、(1)看護学部卒業者、(2) 来日動機が「介護資格を取りたい」「介護技術の高さ」等で、「日本の介護そのものに興味 がある人」が多いことを指摘できる【表 $3 】 。 49$ 人中、看護学部出身者は 13 人いたが、受 験まで日本に残った 7 人のうち 4 人が合格している。また、合格者 9 人中、 6 人が来日動 機を「介護技術の高さ」「日本の介護資格をとる」としている。

\subsection{1 合格事例 $1:$ 看護の知識が介護福祉士試験に有利}

マニラ首都圏出身の $\mathrm{M}$ さ（女性、20代）は、フィリピンでは看護学部卒だが、看護師 としての職がなく、病院内の役員秘書をしていた。就労年数不足で看護師候補者となれ ず、介護福祉士候補者として来日した。来日動機は「日本で介護資格を取る」である。夫 も看護師として中東で働いている。幸い、Mさんは日本語の成績が良かつた。施設の教 育担当者 $\mathrm{P}$ さは「やはり看護師を（介護福祉士候補者として）選んでよかった。基礎的 な医療知識があり、日本語習得さえうまくいけば、介護福祉士試験問題の理解と解答はで きる。頭の中にすでにある知識を日本語に置き換えれば良いのだから、勉強は楽だと思 う」と話していた（2012 年 8 月、中国地方にて聞き取り）。 


\subsection{2 合格事例 2 : 医療・福祉系専門職が一丸となって学習支援}

ルソン島中部出身の Tさん（女性、30代）の来日動機は「給与の高さ」である。大学で は医療技術を専攻し、医療技術者、医薬品営業職、薬剂師の助手として働いた後、フィリ ピンに夫と子どもを残してEPAで来日した。受入れ施設は病院に併設された特別養護老 人ホームである。着任当初から看護師長の指揮のもと、看護師、薬剤師、介護福禅士、介 護支援訪問員が $\mathrm{T}$ さんら 3 人の候補者たちの教育係となった。薬剤師の Zさん（女性）は 青年海外協力隊経験があり英語を話せるため、着任当初の Tさんらと日本人職員との媒介 者となった。同時に、若手の介護福祉士 2 名（いずれも女性）は彼女らにとって最初の日 本人の友人となった。仕事の後に 2 時間の勉強を続けて疲れたものの、Tさんは無事合格 し、あとの 2 人は中途帰国と不合格であった。Tさんは看護学部出身ではないが、来日前 の職歴から医療施設とその用語に慣れており、受入れ施設でも専門職集団の学習支援を受 けられたことが合格への後押しとなった（2010年 8 月、中国地方にて聞き取り、2013年 4 月、メールで連絡)。

\subsection{3 合格事例 $3:$ 他分野の専攻、家族呼び寄せを目標に努力}

かたや、大学での専攻は林業という、全く畑違いの仕事から介護福祉士候補者として来 日し、合格に至った人もいた。ミンダナオ島中部出身のLさん（男性、30代）の来日動機 は「日本の介護資格を取る」であった。フィリピンでは森林管理の仕事をしていたが、海 外出稼ざのため介護研修を受けた。EPAで介護福祉士候補者として選ばれ、来日直前に、 当時妊娠中だった妻と結婚式をあげた。来日後半年間の日本語研修時、「飲み込みが早い」 と日本語講師から評判が高く、その後、着任した施設では学習支援態勢が良く、試験前は 勤務時間を短縮してもらえた。ごく短い一時帰国を除いては、妻子と別れて日本で働いて きた Lさんにとり「家族を呼び寄せて日本で暮らす」という目標は切実で、その実現のた め日本語習得と試験勉強に励んだ（2012年 8 月、中国地方にて聞き取り）。

\section{6 中途帰国者のその後}

3 年間の実務実習を終えずに中途帰国した 21 人のうち、9 人がフィリピンへ帰国の後に 海外移住している (2013 年 9 月現在)。その行き先は、カナダ 3 人、米国 2 人、日本 2 人 (日本人と結婚)、ドバイ 1 人、タイ 1 人であった。また、不合格帰国者（再受験目的の在 留延長を希望しない場合）は 5 人となった。彼（女）らの「その後」を紹介しよう。

\subsection{1 海外移住事例 1: 看護師免許はパスポート}

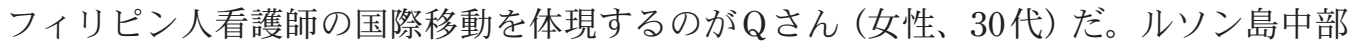
出身の彼女は看護師資格を持っており、中東で看護師としての就労経験があった。来日動 機は「給与の高さ」と回答している。EPAに応募するのと並行してカナダ等にも看護師と 
して求職活動をしていたが、日本行きの話が先に決まったため介護福祉士候補者として来 日した。施設に着任した後にカナダ行きのビザが下りて、2011年 4 月（施設配属から 1 年 5 か月後）に施設を退職し、フィリピンへ戻り 2012 年 8 月に家族とともにカナダへ移住 した。現在は同地で看護師として㗢いている（2010年 8月、中国地方にて聞き取りの後、 2012 年 12 月、メールにて連絡有)。

\subsection{2 海外移住事例 2 : より専門性の高い職を求めて}

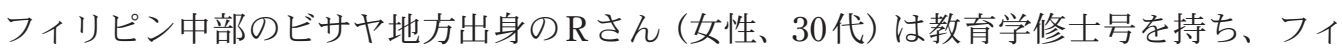
リピンでは高校教師をしていた。海外出稼ぎに行きやすいからと家族に勧められて、介護 研修を受けた。「日本に住んでみたい」との来日動機で、これが初めての海外生活であっ た。しかし、日本語習得が思うように進まないまま研修期間が終わり、施設へ配属される こととなる。2011年8月に筆者が訪問すると、彼女の表情はかたく、「日本人は英語が話 せないのが問題です」と話していた。過疎地にある受入れ施設では、英語を話せる職員は いない。翌年、Rさんはタイで英語教師の仕事を見つけて退職を決め、フィリピンに帰国 した後、タイへ移住したという (2011年 8 月および2012年 8 月、中国地方にて聞き取り)。

\subsection{3 海外移住事例 3 : 諸国を転々とする労働者}

ルソン島南部出身のUさん（女性、30代）は観光学部を卒業し、フィリピンで職を転々 とした後、長姉の出稼ぎ先であるイスラエルに行き、独居老人宅で住み込みの介護士とし て 6 年働いた。帰国後、次なる出稼ぎ先としてEPAに応募したところ採用され、中国地 方の施設に着任した。介護士の就労経験があるので仕事に問題はなかったが、仕事と勉強 の両立が辛かった。2011年10月に中途帰国し、イタリアへ出稼ぎに行くつもりだった が、斡旋料が高すぎて断念した。その後、2012年 9 月に次姉がいるドバイへ行き、住み込 みの介護士として働くが半年で帰国した。2013年 9 月にマニラでUさんと再会したが、そ の時は米系企業のコールセンターで働いていた。社会人となってから海外出稼ぎを繰り返 してきたUさんには、日本は単に「行き先の一つ」だったのである（2010年8月および 2012 年 8 月、中国地方にて、2013 年 3 月、ドバイにて、2013 年 9 月、マニラにて聞き取 り)。

\section{5. まとめ}

\section{1 追跡調査からの知見}

これまで、冒頭に挙げた問 1（どのような属性の人が定着したのか）および問 2（ぞの ような属性の人が合格したのか）に対し、追跡調査からデー夕を提示してきた。最後に、 本研究で得られた知見をまとめておこう。 


\subsection{1 どのような属性の人が定着したのか}

第一に、比較的定着が良かったのは「マニラ首都圈以外の出身者」と言える。中途帰国 者にはマニラ首都圈の人びとが多い。フィリピンでは日本以上に都鄙格差が大きく、地方 により言語が違うこともあり、マニラ育ちの人は田舎に旅行はしても転居することは極め て稀だ。そもそも田舎の生活に慣れていないのである。対照的に、関西地方の大都市圈に ある施設で働く候補者（本研究の追跡対象外）を訪ねると、最寄り駅まで自転車で 5 分、 駅ビル内に国際交流センターがあり、電車に乗ればカトリック教会まで 15 分の距離であ る。日本のアイドル歌手のファンで、お金を貯めてコンサートに行くなど、現実の世界で 日々の生活に楽しみを見つけやすい。ただし、ここで「都会の人は我慢が足りない、地方 出身者は根性がある」と決めつけてしまうのは早計だろう。中途帰国に至る理由はさまざ まで、その背景を慎重に検討する必要がある。腰痛や背中の痛み、メンタルヘルスの問題 を抱えて帰国した人もいる。筆者自身も何度か電話や訪問で通訳をしたのだが、中途帰国 が現実的な解決策だったことが多い。外国人支援団体やコミュニティユニオン、外国語を 話せる人材は、大都市には多いが過疎地ではきわめて少ない。電話やスカイプ（無料のテ レビ電話）を利用した労働相談ができる第三者的な相談機関が必要とされている。

第二に、インターネット環境が定着の助けとなったことだ。マニラ首都圈では日本より も早く公衆無線 LAN (Wi-Fi) が導入されていた。そもそも、EPAへの応募はインターネッ 卜経由で行われたため、来日する候補者はすでにインターネット環境に慣れている。中途 帰国したSさんは「着任当初、寮にインターネットが無かつた。そのため、町で電気店を 探し回り、着任から 1 か月後にようやくインターネットを使えるようになった。その 1 か 月にとてもストレスがたまった」という。家族との連絡手段に、また候補者同士の情報交 換に、スカイプとフェイスブックは必需品であった。

第三に、地域社会としての受入れである。候補者の着任は、まず地方新聞で報道される ことが多い。それが契機となり、近隣住民や施設利用者から声をかけられるほか、農産物 の差し入れがあれば経済的にも助かる。このことを窮屈に感じる候補者もいるだろうが、 緊張感を伴う職場での日本人職員との付き合いに比べ、近隣住民との交流は楽しい経験と して語られることが多い。また、地域の夏祭りでの浴衣姿の写真はよくフェイスブックに アップされている。このように、地域社会から歓迎されていると感じ、行事に参加するな ぞの形で地域社会へ参加していくことは長期的に定住を促進するであろう。

\section{1 .2 どのような属性の人が合格したのか}

サンプル数の限界から属性と合格の因果関係は統計的に明らかにはならない。しかし、 合格者の属性データから看護学部卒は知識面で有利であることがわかる。また、来日の動 機としては、合格者には「日本の介護技術」「介護資格」そのものへの興味があった。日 本で得られる比較的高額の給与だけが動機では、仕事はできても介護福祉士試験への勉強 
には困難がある。従って、フィリピンで看護学部卒だが看護師としての職歴は短いため第 三国へ看護師として出稼ざに行くことは難しく、さらには日本の介護技術や資格に興味が ある人材が、介護福祉士候補者として「成果が出やすい」と言えるだろう。

\section{2 国際労働力移動の第一歩としてのEPA}

追跡対象の 49 人中、中途帰国後に他国で就労・移住する人が 9 人いた。カルロス [2012] や平野 [2010] が指摘したとおり、それは専門職としての将来性を勘案した移動で あった。

そして、看護学部卒業者は諸刃の剣とも言えるのである。すなわち、彼 (女) らには、 合格可能性と海外流出の可能性が同時にある。49人中、看護学部卒の 13 人のうち、介護 福祉士試験の合格者は 4 人、不合格者は 4 人であった。一方、中途帰国による海外流出者 は 5 人にのぼる。彼 (女) らは医療知識があり介護福祉士試験には有利だが、一方で、看 護師資格を武器として他国への移住もしやすい。

このようなケア労働者の国際移動を促進するのが、インターネットによる低コストの通 信手段であった。フィリピンでは、スカイプとフェイスブックが 2009 年頃から急激に普 及した。彼 (女) らは四年制大学卒で、英語運用能力に加えて来日後は日本語習得能力も あり、インターネットで仲間同士はもちろん、グローバルな親族・友人ネットワークを駆 使して情報収集している。そこで有益な転職情報が得られることは多い。彼らは決して 「弱者」ではない。知識とネットワークを持つ、「フェイスブック世代の高学歴中間層」と でも呼ぶべき流動性の高い人びとなのである。こうした人材を日本につなぎとめておくの は容易ではない。

\section{3 結論と今後の課題}

以上の議論から、「定着」と「合格」が同時に要求される EPAの介護福祉士候補者に向 くのは、定着要因としての「マニラ首都圈以外の出身者」および合格要因としての「看護 学部出身で日本の介護に興味がある人」を備えた人だと言える。しかし、「看護師職歴が 十分に（目安として 3 年以上）あると他国へ移動しやすい」ことを考慮すると、「マニラ 首都圈以外出身で、看護学部出身だが職歴は浅く、日本の介護に興味がある人」が良いと 暫定的に結論づけられよう。とはいえ、今後の課題とすべき点は多い。

第一に、本研究では、合格者に対して「各施設で、どのように勉強させたか」を分析対 象に入れていない。今後、各施設への聞き取りをもとに考察したい。第二に、本稿では 49 人の候補者たちの属性から、出身地と大学での専攻を変数として分析したにすぎない。 年齢や未婚・既婚の別、出身家族の階層等、さらに細かい分析が必要となる。第三に、本 稿では受入れ施設がある場所を「過疎地・地方都市」とひとくくりにしてしまったが、そ の立地や周辺の交通手段にはもちろん差異がある。さらにきめ細やかな地域類型化をした 
上での「定着の容易さ」の分析が必要である。第四に、今後は 2 期生以降も視野に入れる ことである。1 期生は残念ながら「試金石」とされて中途帰国者が多く出たが、 2 期生以 降は学習支援の充実が図られている。また、民間企業により現地で「EPA予備校」が開設 されている。今後は 2 期生以降も視野に入れて調査を続けたい。

日本社会の高齢化は止まらない。介護人材を国内外で確保・育成することは喫緊の課題 であり、雇用側と労働者側の双方にとって利益のある送出／受入れ制度に向けた改善が進 むことを期待したい。

\section{付記}

本稿は、科学研究費助成研究「地方都市・過疎地域における外国人介護者定着促進のための学 際的研究」（平成23-26年度、基盤 C、代表：静岡県立大学・高畑幸、課題番号23530714）の成 果の一部である。調査にご協力いただいた皆様に感謝する。

注

1）筆者は、社団法人国際厚生事業団主催によるフィリピン人看護師・介護福祉士候補者受入れ 施設EPA担当者対象の就労前説明会 $(2011$ ・2013 年度）において「フィリピン人看護師・介 護福祉士候補者を迎える準備」に関するガイダンス講義を担当しており、すでに本調査での知 見を順次、受入れ現場へフィードバックしている。

2）厚生労働省ウェブサイトhttp://www.mhlw.go.jp/bunya/koyou/other22/（2013年 9 月 10 日アク セス)

3）ただし、2011年度から、フィリピン人介護福祉士候補者には来日前と後に各半年間の日本 語研修を行うようになつた。

4）介護福祉士資格は 2011 年度までは専門学校で 2 年間学ぶと無試験で取得できたが、 2012 年 度入学者以降は専門学校卒業生にも国家試験受験が課せられるようになった。そのため「就労 コース」と資格取得要件に差がなくなり「就学コース」は廃止された。

5）厚生労働省ウェブサイト http://www.mhlw.go.jp/bunya/koyou/other22/（2013 年 9 月 10 日アクセ ス)

6）例えば、イタリアに介護士として渡航する場合、渡航費込で 50 万ペソ（日本円で約 110 万 円）が必要だという（2013年 9 月 3 日、マニラ首都圏で帰国者に聞き取り）。

7）高齢化率および外国人人口比率は 2010 年の 20 市町および全国の平均值。総務省および法務 省統計より算出。過疎地域市町村数（平成 22 年国勢調査による）は、全国過疎地域自立促進 連盟ウェブサイトを参照。 www.kaso-net.or.jp/index.htm（2014 年 2 月 5 日アクセス）

8）厚生労働省ウェブサイト http://www.mhlw.go.jp/stf/houdou/2r9852000002ycsb.html（2013 年 9 月 10 日アクセス)

\section{文献リスト}

安里和晃, 2012 ,「外国人候補者・受け入れ先の実態と懸念される労働市場への影響とは EPAは 介護・看護現場を変えたか」『Posse』16：141-153.

Carlos, Maria Reinaruth D., Chizuko Sato, 2011, “The Multi-step International Migration of Filipino Nurses : The Propensity to Migrate among Filipino Nurses in Dubai”, 『国際社会文化研究所 
紀要』13:40-61.

カルロス、マリア・レイナルース・D， 2012，「フィリピン人労働者の多段階的移動の文化から 見た介護士の日本への定着の課題」『日本国際文化学会年報』10:127-135.

後藤由美子, 2011, 「外国人介護士受入れに関する一考察一インドネシア人介護福祉士候補者受 け入れ調査を通して」『高知女子大学紀要 社会福祉学部編』60：53-64.

平野裕子，2010，「二国間経済連携協定に基づく外国人看護師の導入一看護師の国際移動と日 本における現実」『保健医療社会学論集』21(2) : 12-29.

Hirano, Yuko, Reiko Ogawa \& Shun Ohno, 2012, “A Comparative Study of Filipino and Indonesian Candidates for Registered Nurse and Certified Care Worker Coming to Japan under Economic

Partnership Agreements”『東南アジア研究』49 (4) : 594-610.

伊藤るり・足立眞理子 (編著)，2008，『国際移動とく連鎖するジェンダー>再生産領域のグロー バル化』作品社.

川村よし子・野村愛, 2010,「介護のためのミ二辞書を組み入れた辞書ツールの開発」『日本語教 育方法研究会誌』17 (1)：22-23.

Kingma, Mireille, 2006, Nurses on the Move: Migration and the Global Health Care Economy, Cornell University Press.

落合恵美子， 2008，「アジアにおけるケアネットワークと福祉ミックス一家族社会学と福祉社会 学との結合」『家族研究年報』33:3-20.

Ogawa, Reiko, 2012, “Globalization of Care and the Context of Reception of Southeast Asian Care Workers in Japan”,『東南アジア研究』49 (4) : 570-593.

小原寿美・岩田一成，2012，「EPAにより来日した外国人看護師候補者に対する日本語支援：国 家試験対策の現状と課題」『山口国文』35：124-114.

大野 俊, 2010, 「看護・介護分野における日本の労働市場開放をめぐる国際社会学的研究の成 果と課題」『保健医療社会学論集』21(2) : 35-52.

小川全夫, 2009,「外国人介護福祉士導入をめぐる論点一誤解から理解へ」『九州大学アジア総合 政策センター紀要』3:67-76.

中井久子， 2011，「フィリピン人介護福祉士候補者と受け入れ施設の意識から見た EPA制度の課 題」『大阪人間科学大学紀要』 $10: 1-11$.

布尾勝一郎, 2012,「言語政策的観点から見た EPA看護師・介護福祉土候補者受け入れの問題

点」『社会言語学』 $12: 53-71$.

三枝令子，2012，「介護福祉士国家試験の日本語：外国人介護従事者にとってのことばの問題」

『介護福祉学』19（1）：26-33.

立川和美，2009，「介護施設での食事場面におけるコミュニケーションについて—外国人介護 労働者に対する日本語教育にむけて」『流通経済大学社会学部論叢』20 (1) : 1-14.

高畑 幸, 2011, 「外国人ケア労働者をケアするのは誰か一経済連携協定により受け入れたフィ リピン人介護士候補者をめぐって」『社会分析』38：43-60.

国際厚生事業団サイト http：//www.jicwels.or.jp/EPA/ (2013年9月 10 日アクセス)

(たかはた さち／静岡県立大学准教授) （原稿受付 2013 年 12 月 7 日 掲載決定 2014 年 5 月 5 日） 